\title{
RETHINKING CONCEPT OF RAPE UNDER THE ISTANBUL CONVENTION: UKRAINIAN EXPERIENCE
}

\author{
Alina SOLOVIOVA \\ Professor of Criminal Law and Criminology at the "National Academy of \\ Management" Ukraine \\ E-mail: altoryk10@ukr.net
}

\begin{abstract}
The article provides a comparative legal analysis of rape in the criminal law of Ukraine and some foreign countries. The paper aims to analyse countries that share the same historical backgrounds, such as Russia, Belarus. The study of foreign experience in the criminal legal protection of sexual freedom and sexual integrity has become essential for Ukraine. By comparing the same legal norms, principles, and institutions, it is possible to determine the general patterns of development and prospects for improving the country's domestic criminal law.

The author draws attention to the advantages and disadvantages of the previously existing definition of rape in the criminal law of Ukraine as sexual intercourse with the use or with the threat of violence against the victim. The article separately analyses the norms of rape in foreign countries, where the concept of rape as forced sexual intercourse still exists.

In Ukraine, rape is now defined as the commission of sexual intercourse (penetration) with another person without the consent of the latter. Among the shortcomings of the existing concept of rape in the criminal law of Ukraine, the author names the unresolved legislative issue of qualifying an act when the perpetrator has sexual intercourse with a victim whose behaviour he thoughtlessly took as a consent.
\end{abstract}

Keywords: rape, crime, criminal law, subject of a crime, voluntary consent, victim, actus reus, sexual intercourse. 


\section{Introduction}

The study of the criminal legal protection of sexual freedom and sexual integrity in different countries is of high importance as the study of foreign experience allows for the acquisition of in-depth knowledge of the law of a country, since the specific features of the law are clearly identified when compared with other legal systems and legal regimes.

Ukrainian criminal law is currently facing several problems in qualifying the actions of a perpetrator as rape. According to the previous version of the provision on criminal responsibility for rape under the Criminal Code of Ukraine, rape was understood as natural sexual intercourse between persons of different sexes, combined with violence, threats of violence, or committed by taking advantage of the victim's helpless state. At the same time, the list of unlawful actions which could be qualified as rape were exhaustive. Current legislation defines rape as the lack of voluntary consent of the victim, which leads to problems both in the theory and practice of criminal law.

\section{The concept of rape in Ukraine: the historical retrospect}

According to the previous version of the provision on criminal responsibility for rape under the Criminal Code of Ukraine, rape was understood as natural sexual intercourse between persons of different sexes, combined with violence, threats of violence, or committed by taking advantage of the victim's helpless state. The Resolution of the Plenum of the Supreme Court of Ukraine 05/30/2008 № 5 "On judicial practice in cases of crimes against sexual freedom and sexual inviolability of the person" also clearly claimed that the actions of a person who has obtained the consent of a person of the opposite sex to have sexual intercourse in another way, for example, by intrusive offers to have sex or by deception or abuse of trust (declaration of love, knowingly false promise to marry, pay for sexual services, etc.) could not be qualified under Article 152 of the Criminal Code (Decision of the Supreme Court of the Republic of Ukraine, 2008). Therefore, the concept of rape was exhaustive. The absence of violence or the threat of violence completely excluded the corpus delicti.

Considering the retrospective of criminal liability for rape, it is important to establish a link between certain religious beliefs and a crime committed against sexual freedom such as rape. Religious teachings acquired, at the will of the legislator, legal meanings that determined the norms of behaviour and legal status of women.

In Ukraine, the reaction of society to the protection of human sexual freedom has significantly changed throughout the history. This is quite understandable, given the fact that any society goes through various periods of civilizational development. The spread of sexual violence dates back to ancient pre-Christian marriage rites. One of the examples of these rites could be bride kidnapping. This form of marriage aroused enmity between the clans, which later transformed into "compensation" or "ransom" of the bride and then into 
the sale of the bride by her relatives by mutual consent of the relatives of both parties: the act of violence is replaced by an agreement with the rite.

Ukraine has deep legal tradition, having inherited most legal norms from the Soviet Union law. The criminal law is not an exception. According to the Criminal Code of the Ukrainian Soviet Socialist Republic (1922) rape was determined as intercourse with the use of physical or mental violence or through the use of the helpless state of the victim. Such actions were punishable by imprisonment for a term of at least three years. If the rape resulted in the victim's suicide, the sentence was increased by at least five years. For the first time in criminal law, the use of the helpless state of a victim was mentioned as one of the criteria of rape.

The next legislative act in force on the territory of Ukraine was the Criminal Code of the URSR (1927), according to which rape was defined as sexual intercourse with the use of physical violence, threats, intimidation, or using, by deception, the helpless state of the victim and was punishable by imprisonment for up to five years. This legislation established responsibility only for the rape of a woman.

Later, in the Criminal Code of 1960, sexual crimes were not singled out by the legislation, but were placed in Section III of the Criminal Code of 1960 as "crimes against life, health, liberty, and dignity of the person." The definition of rape did not change. According to article 117 of the Criminal Code of the USSR (1960), rape was understood as sexual intercourse with the use of physical violence, threats, or using the helpless state of the victim.

According to the Criminal Code of 1960, only a man could commit such a crime as rape. Violent sexual assault by women on men in judicial practice was regarded as crimes against the person (causing bodily harm, illegal imprisonment, offense, etc.) or as hooliganism. The reference to a man as a victim of rape became a novelty of the Criminal Code of (2001), conditioned by the desire to provide equal legal protection of the sphere of sexual life of persons of any sex. According to Article 152 of the Criminal Code (2001), both a woman and a man could be a victim of rape. In the first case, the direct, physical perpetrator of the crime is a man, and the victim a woman. In the second, on the contrary, the perpetrator is a woman, and the victim a man, while any person can be an accomplice. In 2001, the definition of rape became clearer concerning the use of a threat as a means of overcoming the resistance of the victim and achieving a criminal goal in comparison with the Criminal Code of 1960 .

For at least the last 100 years, up to 2017, the concept of rape has not changed, being based on the concept of violence. This approach remained relevant for Ukraine due to the closeness of the legal tradition and similarity of legislation in the Soviet Republics and persisted in some Eastern European countries currently. 


\section{The concept of rape understood as the use of force, threat of force or coercion}

As noted earlier, previously the Ukrainian Code identified "violence" as a key element of the crime of rape. Some countries of Eastern Europe, such as Bulgaria, Belarus, the Russian Federation and others, still have legal definitions of rape based on force, threat of force or coercion, rather than lack of consent.

The Plenum of the Supreme Court of the Republic of Belarus, in its ruling No. 7 of September 27, 2012, explains to the courts that rape (Article 166 of the Criminal Code of Belarus) means sexual intercourse with a woman committed with the use of violence or the threat of its use against the victim or her relatives (against her will) or using her helpless state (against the will of the victim) (Decision of the Supreme Court of the Republic of Belarus, 2012).

The Republic of Kazakhstan, which is one of the former Soviet republics also shares this approach. According to Part 1 of Art. 120 of the Criminal Code of the Republic of Kazakhstan, rape is sexual intercourse with the use of violence or with the threat of its use against the victim or other persons, or using the helpless state of the victim, and is punishable by imprisonment for a term of five to eight years (Criminal Code of the Republic of Kazakhstan, 2014).

The legal assessment of violence in the classification of crimes against sexual inviolability and sexual freedom played a major role in connection with the construction of the offenses. Violence or the threat of its use in the corpus delicti was a constructive sign of actus reus a, way of committing a socially dangerous act. Actus reus of rape consisted of two consecutive actions: physical violence or the threat of its use by a male person to the victim and subsequent sexual intercourse in, as previously defined, natural form. Rape using a helpless state, as a rule, was committed without prior physical or mental violence against the victim. The courts base their conclusions on the helpless state of the injured person on an assessment of all the circumstances of the case, without giving preference to any one piece of evidence, and should be duly motivated in the judgment indicating the specific signs by which a state is recognized as helpless.

In the cases studied, the grounds for recognizing the state of the injured person as helpless include the young age of a person, mental retardation, disability, and alcohol intoxication. Thus, the Molodechno District Court, by a verdict of March 25, 2011, found K. guilty of attempted sexual intercourse against the will of the victim with the use of violence against the victim L. and using her helpless state (part 1 of article 14 and part 1 of article 166 of the Criminal Code of the Republic of Belarus). According to the conclusion of the outpatient forensic psychiatric examination, L., taking into account, her mental state, was able to understand the nature and significance of the actions performed with her and could resist. At the same time, it can be seen from the materials of the case that the victim $\mathrm{L}$. was a disabled person as a result of a severe traumatic brain injury, the consequences of which were also partial 
paralysis of the left arm and leg. At the hearing, in addition, it was established that the accused knew for certain that the victim was in a state of pregnancy (Aniskevich, Krivaya and Dulko, 2012).

Historically, victim physical resistance was an element which had to be proven to convict a defendant of rape. Chapter 22 of Deuteronomy stipulates the following punishments for illicit sexual relations: "If a man has relations with a betrothed virgin whom he finds in the city, both will be stoned to death - she, because she did not cry for help, being in the city where she could get help, and he for "humbling her". But if a man finds a betrothed virgin in the field and forces her into sexual relations, only he will die. Because she cried and there was no one to help her, she was an unwilling party and therefore not guilty".

Even in the $20^{\text {th }}$ century, the interpretation of the concept of rape through the concept of violence led to the issue of victim's behaviour. Some Ukrainian scientists stressed that in some cases, the conduct of the victim might be provocative and should be taken into account when qualifying the actions of perpetrators and imposing criminal penalties. Kozlov notes that in the case when a man's sexual harassment had a certain basis, when for example the woman invited her husband to spend the night with unimpeded kisses, caresses, some violence should be considered appropriate, for example, undressing (Kozlov, 2002). Some attempts have been made to solve this problem at the legislative level. Korzhansky proposed to supplement Article 152 of the Criminal Code of Ukraine (rape) with the following note: "It does not entail criminal liability under Part 1 of Art. 152, if the behaviour ... of a woman gave the man grounds for a conscientious error regarding her consent to sexual intercourse" (Korzhansky, 2004).

Some scholars have even suggested making certain demands on the victim's resistance in order for it to be considered valid rape. These scientists support the position that in cases where the perpetrator and the victim have previously known each other, physical violence can be stated only if the woman did everything she consciously and subconsciously considered possible to counteract and repel the abuser, and the victim's reluctance to have sex was obvious for the rapist (Korchovy, 1998).

With the development of criminal law, it became clear that the victim of rape can be both a man and a woman, and the degree of resistance of the victim cannot be used as a basis for qualifying the actions of the offender.

\section{The concept of rape through the concept of consent of the victim}

In order to outline the problem of interpreting rape through the lack of consent to sexual intercourse, we will give as an example from case law, which significantly affected the legislation of different countries, including Ukraine.

In 2004, the European Court of Human Rights found that the decisive factor in classifying a crime as rape was the lack of consent of the victim and not the use of violence to overcome the victim's resistance (M.C. v Bulgaria). The case concerned M.C., who alleged that she had been raped separately by 
two men on 31 July and 1 August 1995, when she was 14 years old. The events took place at night after the three of them went to the disco bar. She met one of the men the night before. Another man was the brother of a classmate. The girl reported the rape to the police. In November 1995 the public prosecutor instituted criminal proceedings for the rapes and referred the case to an investigator.

On March 17, 1997, the prosecutor terminated the criminal investigation due to the fact that force or threats against M.C. had not been established. He stated that there was no resistance on her part or attempts to seek medical help. The girl appealed against this decision to the regional prosecutor's office and the Chief Prosecutor's Office. However, the appeals were rejected on the same grounds. For example, in response to a second appeal, the prosecutor stated that there were no signs of physical force, such as beatings or torn clothing. He recalled that, although he found it unusual for a minor girl to have sexual intercourse twice in a short period of time with two different people, that fact alone was not sufficient to establish the commission of the crime, in the absence of other evidence and inability to gather additional evidence (European Court of Justice, No. 39279/98, 2003).

In December 1997, the victim appealed to the European Court of Human Rights, arguing that the national law enforcement system, which required evidence of physical resistance on the part of the victim, was imperfect and that the perpetrators' actions remained unpunished (European Court of Justice, No. 39279/98, 2003).

This case is the one which shows that understanding the concept of rape through the concept of violence does not provide complete legal protection. In Ukraine, the most significant change in the concept of rape at the legislative level took place on December 6, 2017 when the rule on liability for rape was completely changed and brought into line with the provisions of the Council of Europe Convention on preventing and combating violence against women and domestic violence, better known as the Istanbul Convention. Despite the fact that Ukraine has not ratified the Istanbul Convention, Ukraine adopted the Law (6 December 2017) "On Amendments to the Criminal and Criminal Procedure Codes of Ukraine in order to implement the provisions of the Council of Europe Convention on Preventing and Combating Violence against Women and Domestic Violence". In the current version, in accordance with Part 1 of Article 152 of the Criminal Code of Ukraine, rape is the commission of sexual acts involving the vaginal, anal or oral penetration of another person's body with the use of the genitals or any other object, without the voluntary consent of the victim. According to the note to this article, consent is considered to be voluntary if it is the result of the free will of the person, subject to the circumstances.

However, the concept of consent to sex is superficial, which can lead to the complications of the investigation of such cases. The law states that "consent is considered voluntary if it is the result of a person's free will, taking into account the accompanying circumstances." But how exactly a person should give such consent and how a partner should receive it is not specified. 
Active verbal consent is counted, but in this case, in court, it is the word of the victim against the word of the abuser. In the opinion of many scholars, there are some difficulties in defining and legislating the signs of consent (Safiullin, 2011).

The very concept of consent can be divided into three elements: the expression of will, the ability to make decisions and the ability to express decisions. If only one of the above elements is missing, there is no consent to sexual intercourse. Defining the expression of will as a separate element of consent is problematic because it creates too wide a boundary for sexual intercourse without consent.

Within the framework of the problem considered by us, the question of "friendly" rape is of interest. Most often such cases occur when the victim is visiting a friend, or invites him/her to their home. In some cases, the act of rape takes place with the passive consent of the victim, when the victim does not want, but does not prevent the perpetrator, which is considered as a sign of consent by an offender. For example, in the jurisprudence of the countries of South-Eastern Europe, there were cases when a person had sexual relations that they did not want, but did not express their objection. In previous practice, it was believed that the internal hidden objection to sexual intercourse was small. Such a conclusion will no longer be possible with the current legal solution. Recent case law has already taken the position that the victim is not obliged to disagree with a sexual act in order for a sexual crime to take place. In the Zagreb District Court case in 2013, the injured party kissed the defendant, took off her clothes and lay down in the back seat of the car and allowed the defendant to have sex with her because when she moved the tools from the back seat of the car to the trunk, she noticed that the defendant had a knife, so she was afraid of him. Given the conduct of the victim after the commission of the crime, the court concluded that all elements of the crime of rape were present (Case ŽS u Zagrebu, 5-K-133/2013).

There is no indication in the Ukrainian legislation of a concept of error in the consent of the victim. Croatian scholars note that the spread of punitive errors is questionable not only from a purely practical but also from a systemtheoretical point of view. Namely, the implementation of this exception hinders the logical coherence of the general and special part of criminal law (Rittossa and Martinović, 2014).

Robinson stresses that "the consent of the victim, which allows distinguishing the desired from the impermissible, is purely subjective, and the task of the legislator is to develop an effective definition of consent" (Robinson, 1997). The problem of uncertainty of the concept of consent leads to insufficient legal protection of sexual freedom. Thus, we decided to study the most common types of uncertainty in the concept of consent. 


\section{Rape v. fraud}

One situation is when consent was obtained by fraud or by deception. Different criminal law schools draw more attention to sexual intercourse by fraud. In Eastern Europe in general and in Ukraine in particular, the concept of rape by fraud is not determined or widely used. However, the term has already found its use in several states in the United States such as California, Tennessee, Alabama, and Michigan. According to Paragraph d, Part 4 art. 261 of the Penal Code of California the victim was incapable of resisting was not aware, knowing, perceiving, or cognizant of the essential characteristics of the act due to the perpetrator's fraud in fact. Patricia J. Falk (1998) stresses that rape by fraud is perpetrated across six general categories (with some overlap): (1) fraudulent treatment, (2) sexual impersonation, (3) sexual scams, (4) sexual theft, (5) abuse of authority, and (6) sexual extortion (Falk, 1998).

The first type is characterized by fraudulent medical, psychological, psychiatric, and religious treatment used to obtain sexual intercourse. The case law knows the case of McNair v. State. According to the decision of the Supreme Code of Nevada 825 P.2d 571 (1992), McNair, a graduate of Stanford University School of Medicine, who was a solo practitioner in obstetrics and gynaecology, assaulted his victims during the routine course of medical examinations conducted in McNair's examining room. When a physician succeeds in the penile penetration of a patient under the guise of performing a medical examination, a sexual assault is committed by fraud and deceit and without the victim's consent. An older case is Don Moran v. People, in which a doctor deceived a fifteen-year-old girl into having sexual intercourse with him. The defendant persuaded the young woman to acquiesce using a panoply of deceptive statements: the girl's father had authorized the sexual connection, the doctor used the same technique on all women whom he treated, and the alternative was a painful medical procedure that would probably kill her (Falk, 1998).

The main reason for the increased importance of criminalization of rape by fraud is that the free consent cannot be given when a person does not understand what he/she agrees to.

Rape by fraud may also take place when a perpetrator pretends to be someone else in order to obtain sexual intercourse. In this case, we should mention a relatively recent case. In 2010, it was first reported that a man deceived a woman into consensual sex by lying about being Jewish, unmarried, and interested in a long-term relationship. If [the complainant] had not thought the accused was a Jewish bachelor interested in a serious romantic relationship, she would not have co-operated. .... The court is obliged to protect the public interest from sophisticated, smooth-tongued criminals who can deceive innocent victims at an unbearable price - the sanctity of their bodies and souls (Kashour, v. State of Israel 561/08, 2010). The Israeli penal code regulates such situation in the article 345, which states (a) If a person had intercourse with a woman - (2) with the woman's consent, which was obtained by deceit in respect of the identity of the person or the nature of the act - her consent to 
intercourse did not constitute free consent. then he committed rape and is liable to sixteen years imprisonment (Penal Law of Israel, 1977).

Another case took place in the United Kingdom. In November, 2015, the British woman Gayle Newland was sentenced to eight years in prison for pretending to be a man as a means of having sex with an unnamed woman of the same age. Newland had made her female victim believe that she was a man by means of deception and used the deception in order to have sex with her on more than 10 occasions. On 12th November, 2015 Gayle Newland was found guilty of sexual assault and sentenced to eight years imprisonment. She won an appeal against her conviction and was released on 12th October, 2016 pending a retrial but was subsequently found guilty and sentenced to six years imprisonment on 20th July 2017 (O'Shea, 2018).

The Ukrainian criminal code does not specifically mention rape by fraud. However, it points out that consent is considered to be voluntary if it is the result of the free will of the person, subject to the circumstances. This indication does not solve the problem of qualification of the acts described above. Thus, in our opinion, in order to reduce the problems in qualifying rape by fraud, it is necessary to include a clause for this type of action in the norm on rape of the criminal law of Ukraine.

\section{Rape v. theft/making of without payment}

Sexual acts against women who are engaged in prostitution have never received adequate legal protection (Miller and Schwartz, 1995), interviewing 16 street prostitutes in Los Angeles (USA), identified only one who had never experienced sexual violence while working.

Some scientists and practitioners of criminal law believe that the behaviour of a prostitute becomes highly reckless in certain situations. Eightyfour law enforcement officers who practice criminal prosecution and justice in cases of the studied category (judges, investigators, prosecutors, their deputies and assistants) were asked a question: "Is forced sexual intercourse with a prostitute who refused to serve a client who paid for sexual services rape?" According to the survey, $66.2 \%$ of respondents answered positively, and $33.8 \%$ gave a negative answer (Mikhoparkin and Sidorov, 2008)

Another problematic point arises in the qualification of acts, when a person engages in sexual activity, expecting to receive funds, but does not receive them, i.e., consent was obtained fraudulently. The case Regina V Linekar represents this existing legal uncertainty. L appealed against his conviction for rape. His victim was a woman working as a prostitute. He said that he had simply made off afterwards without payment. He was convicted on the basis that he had procured the act under false pretence. (Judgment, England and Wales, 1994). He was not sentenced as he “... was not guilty of rape. If anything, the appellant was guilty of an offence under section 3 of the 1956 Act which was not an alternative that was put to this jury.' With regard to this type 
of crime, it is important to note that in most countries of Eastern Europe, for example in Ukraine, prostitution is an illegal occupation. Thus, if a person receives consent to have sexual intercourse, even if a certain payment was agreed, which was not subsequently made, these actions cannot be qualified either as rape or as fraud under Ukrainian law.

Despite the fact that prostitution is not a legal activity according to the norms of Ukrainian legislation, by its nature, if this kind of activity were legalized, it could be considered a service. The problem would still arise, since not paying for certain services in a restaurant or hotel is not understood under criminal law of Ukraine as a type of fraud or any crime against property.

\section{Rape v. corruption/extortion}

The term sextortion has become popular over the past decade. The International Association of Women Judges (IAWJ) defines the term as '[a] form of sexual exploitation and corruption that occurs when people in positions of authority whether government officials, judges, educators, law enforcement personnel, or employers seek to extort sexual favours in exchange for something within their power to grant or withhold. In effect, sextortion is a form of corruption in which sex, rather than money, is the currency of the bribe'. Incidents of sextortion have been prosecuted under various criminal statutes, including as extortion, bribery, breach of trust, corruption, sexual coercion, sexual exploitation, sexual assault, child pornography, and even computer hacking. In Canada, Section 122 of the Criminal Code, which penalizes the breach of trust by a public officer, has most often been applied in sextortion cases. In Tanzania, Michael Ngilangwa, a teacher was charged under Section 25 of the Prevention of Corruption Act No. 11 of 2007 for demanding sexual intercourse as a condition for favouring a student. He was convicted and sentenced to pay a fine of 500,000 Tanzanian shillings or serve a year in prison.

The qualification of "sextortion" as a particular crime, as well as its attitude to one or another group of crimes, will depend on the state's legal system itself. An important factor for qualifying sextortion as corruption is a broad definition of a bribe. Some countries broadly define term "bribe or illegal benefits/gains" that can be provided or received.

According to the Criminal Code of Ukraine, unlawful gain means "money or other property, benefits, privileges, services, intangible assets, any other benefits of intangible or non-monetary nature, which are offered, promised, provided, or received without legal grounds"; any other benefits of an intangible or non-monetary nature, for example, the receipt by an official of any information; awarding honorary titles that have no state significance; meeting the sexual needs of the official (Criminal Code of Ukraine, 2001).

Ukrainian law also includes sanction for coercive sexual intercourse. This regulation covers such acts as "coercion of a person without his / her voluntary consent to commit an act of a sexual nature with another person, 
coercion of a person without their voluntary consent to perform an act of a sexual nature with a person from whom the victim is materially or officially dependent".

According to the part 3 of article 154 of the Criminal Code of Ukraine it is a crime to coerce a person "without their voluntary consent to perform an act of a sexual nature with a person from whom the victim is materially or officially dependent with the threat of destruction, with damage or seizure of the property of the victim or their close relatives, or with the threat of disclosure of information that discredits them or their close relatives" (Criminal Code of Ukraine, 2001).

This rule does not provide adequate protection of sexual freedom for several reasons. First, the very phrase "coercion of a person without his/her voluntary consent" is imperfect and from a philological point of view, absurd. According to the Cambridge dictionary, coercion is "the use of force to persuade someone to do something that they are unwilling to do". Therefore, the term coercion excludes voluntary contest.

Secondly, Ukrainian law consists an exhaustive list of actions that should be punished according to this article. Moreover, the Resolution of the Plenum of the Supreme Court of Ukraine On Judicial Practice in Cases of Crimes against Sexual Freedom and Sexual Immunity of a Person strictly defines material and official dependence (Decision of the Supreme Court of the Republic of Ukraine, 2008). "The material dependence of the victim takes place in particular when he is in full or partial maintenance of the guilty person, lives in their living space, as well as when the guilty person by their actions or inaction is able to cause a significant deterioration of the financial situation of the victim. Official dependence occurs when a woman or a man holds a position according to which they are subject to a person who uses coercion, or falls under the control actions of such a person, or the interests of the victim depend on the official position of the guilty person".

Therefore, these provisions do not include several types of dependence, leaving much misunderstanding in practice, such as temporary dependence of patient on a doctor.

Another important aspect of sextortion is a new form of it, brought on by rapidly-developing technologies. There are various types of sextortion that an individual can commit. One type involves an individual who ultimately desires money, and another type involves an individual who ultimately wants some sort of sexual gratification (Robbins, 2019).

A new Pennsylvania law defines sextortion as using a threat of some type of coercion of a victim into a sex act, simulating a sex act, undressing or making a video or image of it. It also determines sexual extortion as "demanding something of value, such as payment, or withholding something, such as a job, to prevent the dissemination of an image or video involving a sex act".

The Ukrainian criminal law system classifies criminal law rules, depending on the system of value on which it encroaches. To understand it in 
practice, we would like to share an example of an action which is often referred to as sextortion under the Criminal Code of Ukraine.

John studies with Christine at the university. One day he picked up her phone to call. However, he decided to scroll through the photos of the girl, where he found her nude photos. After sending them to himself, he later decided to demand $\$ 500$ for not distributing them at the university. These actions will be qualified as extortion as he demands money in return under the Criminal Code of Ukraine.

According to article 189 of the Criminal Code of Ukraine, extortion is requiring "the transfer of another's property or right to property or the commission of any acts of a property nature with the threat of violence against the victim or their close relatives, restriction of the rights, freedoms or legitimate interests of these persons, damage or destruction of their property or property in their possession; under protection, or disclosure of information that the victim or their close relatives wish to keep secret".

However, if we change this situation a bit by replacing John's monetary demand with his desire to have sex with his classmate, Ukrainian law becomes less effective. Extortion has a material element, i.e., only "property, right to property or the commission of any acts of a property nature can be demanded to be qualified as extortion".

Article 154 of the Criminal Code of Ukraine does not solve the problem of criminal law assessment of the actions of a person who induces sexual intercourse by threatening to destroy or damage property or threats to disclose certain information in situations where between the perpetrator and the victim, there is no material or official dependence.

Therefore, the above-mentioned case cannot be seen as the coercion of sexual intercourse by threatening to destroy or damage property or threats to disclose certain information will not be punished under article 154 of the Criminal Code of Ukraine because there is no material or official dependence between John and his classmate, Christine.

\section{Conclusion}

Depending on the peculiarities of legislative approaches to the construction of rape, there are two main concepts of rape: 1) sexual intercourse without the consent of the victim (rape) (Ukraine); 2) violent sexual intercourse (Belarus, Russia).

The norm on rape under Ukrainian criminal law has a long development period. From the initial understanding of rape as a violent intercourse to the current concept of rape as the commission of sexual acts involving the vaginal, anal or oral penetration of another person's body with the use of the genitals or any other object, without the voluntary consent of the victim.

It should be noted that the perpetrator of rape initially could only be a man. A woman could only be an accomplice of this crime (instigator or organizer). Since 2001, according to the criminal law of Ukraine, both a man 
and a woman can be the perpetrator of rape. However, despite the desire of the Ukrainian legislature to improve the criminal law on rape, the current legislative definition of the signs of rape raises a number of practical problems, among which are both the qualification of a factual error regarding the voluntary consent of the victim, and the very concept of consent. Thus, in fact, the Ukrainian legislature mechanically reproduced the definition of voluntary consent formulated in the Istanbul Convention, leaving the decision on the presence or absence of such consent to the discretion of the law enforcement officer.

\section{References}

Aniskevich R., Krivaya V., Dulko L. (2012). O sudebnoy praktike po delam o prestupleniyakh protiv polovoy neprikosnovennosti ili polovoy svobody (st.st. 166-170 UK) (po materialam obzora) [On judicial practice in cases of crimes against sexual inviolability or sexual freedom (Articles 166-170 of the Criminal Code) (based on the review materials)]. Retrieved from www.court.gov.by/upload/OBZORY/sv42012.pdf

Cambridge

Dictionary.

Retrieved

from https://dictionary.cambridge.org/dictionary/english/coercion

Carnegie, S. (2019). Sextortion A crime of corruption and sexual exploitation. Retrieved from www.ibanet.org/Document/Default.aspx?DocumentUid=E5E451C2A883-4518-B0ED-5AAAEBCDD5AA

Criminal Code of the Republic of Kazakhstan. Retrieved from https://online.zakon.kz/document/?doc_id=31575252\&doc_id2=3157 5252\#activate_doc $=2 \&$ pos $=150 ;-116 \&$ pos $2=1855 ;-110$

Criminal Code of Ukraine. Retrieved from, zakon.rada.gov.ua/laws/show/2341-14\#Text

Decision of the Supreme Court of the Republic of Belarus, 2012, September 27, № $\quad 7 \quad$ Retrieved from www.court.gov.by/ru/jurisprudence/post_plen/criminal/vsmen/fa8a32 169f069c1a.html

Decision of the Supreme Court of the Republic of Ukraine, 2008, May 30, № 5 "On judicial practice in cases of crimes against sexual freedom and sexual integrity of a person" Retrieved from https://zakon.rada.gov.ua/laws/show/v000570008/ed20080530/find?text=\%C7\%B4\%E2\%E0\%EB\%F2\%F3\%E2\%E $0 \% \mathrm{ED} \% \mathrm{ED} \% \mathrm{FF} \% \mathrm{EC}$

Falk, P. J. (1998). Rape by Fraud and Rape by Coercion. Brooklyn Law Review. 
Korchovy, M. (1998). Fizicheskoye nasiliye pri iznasilovanii: ugolovnoye pravo i kriminologicheskiye aspekty [Physical violence in rape: criminal law and criminological aspects]. Bulletin of the National Academy of Internal Affairs of Ukraine, 4, 103-108.

Korzhansky, M. (2004). Prezumptsiya nevinovnosti i prezumptsiya vinovnosti: monografiya [Presumption of innocence and presumption of guilt: monograph.] Kyiv: Atika.

Kozlov, A. (2002). Ucheniye o stadiyakh prestupleniya: monografiya [Teaching about the stages of crime: monograph]. St. Peterburg: Legal Center Press.

Mikhoparkin, G. Sidorov, B. (2008). Viktimologicheskiye priznaki osnovnogo sostava iznasilovaniya i ikh optimizatsiya $\mathrm{v}$ ugolovnom zakone [Victimological signs of the main body of rape and their optimization in the criminal law]. No. 1. Retrieved from https://cyberleninka.ru/article/n/viktimologicheskie-priznakiosnovnogo-sostava-iznasilovaniya-i-ih-optimizatsiya-v-ugolovnomzakone-1

Miller J., Schwartz M. (1995). Rape myths and violence against street prostitutes. Deviant Behavior.

O'Shea, S. (2018). Past caring about passing. Graduate Journal of Social Science, 14 (2), 47-57.

Reid, S. T. (1998). Criminal Law. San Francisco: McGraw-Hil.

Rittossa, D., Martinović, I. (2014). Spolni odnošaj bez pristanka i silovanje teorijski i praktični problem [Sexual intercourse without consent and rape - theoretical and practical problems]. Hrvatski ljetopis za kazneno pravo i praks, 21 (2), 509-548.

Robbins A. (2019). Solving the Sextortion Puzzle: Piecing Together a Model State Sextortion Statute. Valparaiso University Law Review, 53 (3), 761-794.

Robinson, P. (1997) Criminal law. New York: Aspen Publishers.

Penal Law of Israel. Retrieved from www.oecd.org/investment/antibribery/anti-briberyconvention/43289694.pdf

Safiullin, R. (2011). Otvetstvennost za seksualnoye nasiliye v otnoshenii podrostkov po ugolovnomu zakonodatelstvu Velikobretanii i SSHA. [Responsibility for sexual violence against adolescents under the criminal law of Great Britain and the United States]. Bulletin of Economics, Law and Sociology, No. 3, 124-127.

Tanzania: Say No To Sextortion. Retrieved from https://genderlinks.org.za/news/tanzania-say-no-to-sextortion/ 